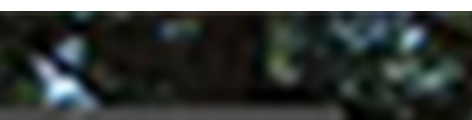

20 MULTI-, INTER-AND

- TRANSDISCIPLINARY

RESEARCH IN LANDSCAPE ARCHAEOLOGY

PROCEEONGS OF THE 3 INTERNATIONAL

C. UNOSCA\%E ARCWAE OLOOY CONSERENCE INROME, ITALY (2018)

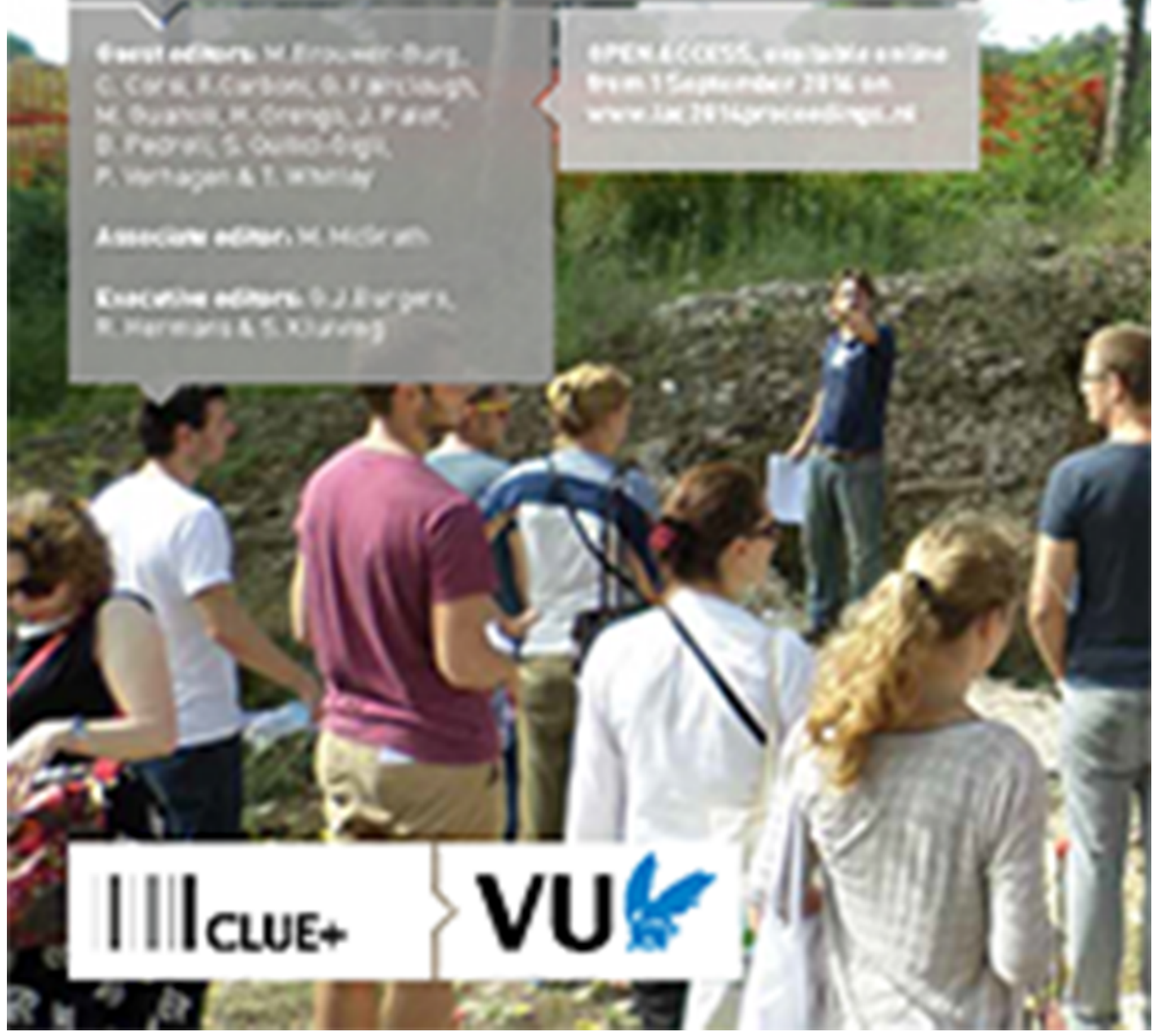




\title{
Archaeology of Commons: a Multidisciplinary Approach to the Reconstruc- tion of Multiple Uses and Conflicts on European Uplands
}

\author{
Anna Maria Stagno \\ Research Group on Cultural Heritage and Landscapes (University of the Basque Country), Laboratory of \\ Environmental Archaeology and History - LASA (Dafist-Distav, University of Genoa).
}

\begin{abstract}
The paper presents a multidisciplinary research project (“Archaeology of Commons: cultural Heritage and Material Evidence of a Disappearing Europe") on the archaeology of common-lands. The main goal of the project is to investigate, by means of historical and archaeological analysis, the intimate social dimension at the base of the common lands management in the context of southern European mountainous regions. Research investigates the dynamic nature of commons starting from the reconstruction of the present organisation of common lands, going back to the complex transformations of common properties in the nineteenth century and analysing the problem of the archaeological visibility of conflicts since the ancien régime. The project will examine how archaeological methods could clarify different aspects of the history of the collective access rights to land, by applying in selected mountain areas methodological approaches based on historical ecology, rural and agrarian archaeology.
\end{abstract}

Keywords: Archaeology, Common-Lands, Conflicts, Environmental Resources, Appropriation

\section{Introduction}

Commons refer to a category of land (meadows, pastures, woods, fields, etc.) used by local social groups (communities, families, etc.) through customary rules and rights. The study of commons involves several disciplines, which address the theme from different (and complementary) research perspectives. The common lands have long been studied by social and legal historians, due to the complexity of their legal status, the conflicts linked to it and the changes connected to the end of the feudal system (Ingold, 2008). Economists, anthropologists, geographers and environmental scientists have approached common lands as a part of the wide and complex issue of common goods and Common-Pool Resources (CPRs) that also includes "global" common goods (as air, water, forests, and biodiversityl and "new" commons las culture, Internet, public facilities, rights to security and to peace, etc.). Economists and anthropologists have demonstrated the sustainability of CPRs management (Agrawal, 2003; Ostrom, 1990). Ecologists and geographers have underpinned the positive externalities of common lands management, in terms of preservation of biodiversity and of cultural landscapes (Rotheram, 2013; Rotherham, Agnoletti \& Handley, 2010). The role of local practices of long-term land management in the history of biodiversification processes land so the possibility to study their relation with the history of common-lands management) has been demonstrated thanks to the contributions of historical ecology. In fact, historical ecology allows identification of historical local practices of environmental resources management and to reconstruct their effects in present ecosystems (Cevasco, 2007; Rackham, 1976).

In the archaeological literature, the juridical status of uplands (and its changes) is rarely studied and the presence of common-lands is considered as a "datum", without going into depth on the material effects of social and jurisdictional common access rights. The rapid development of multi-period mountain archaeology coincided with 


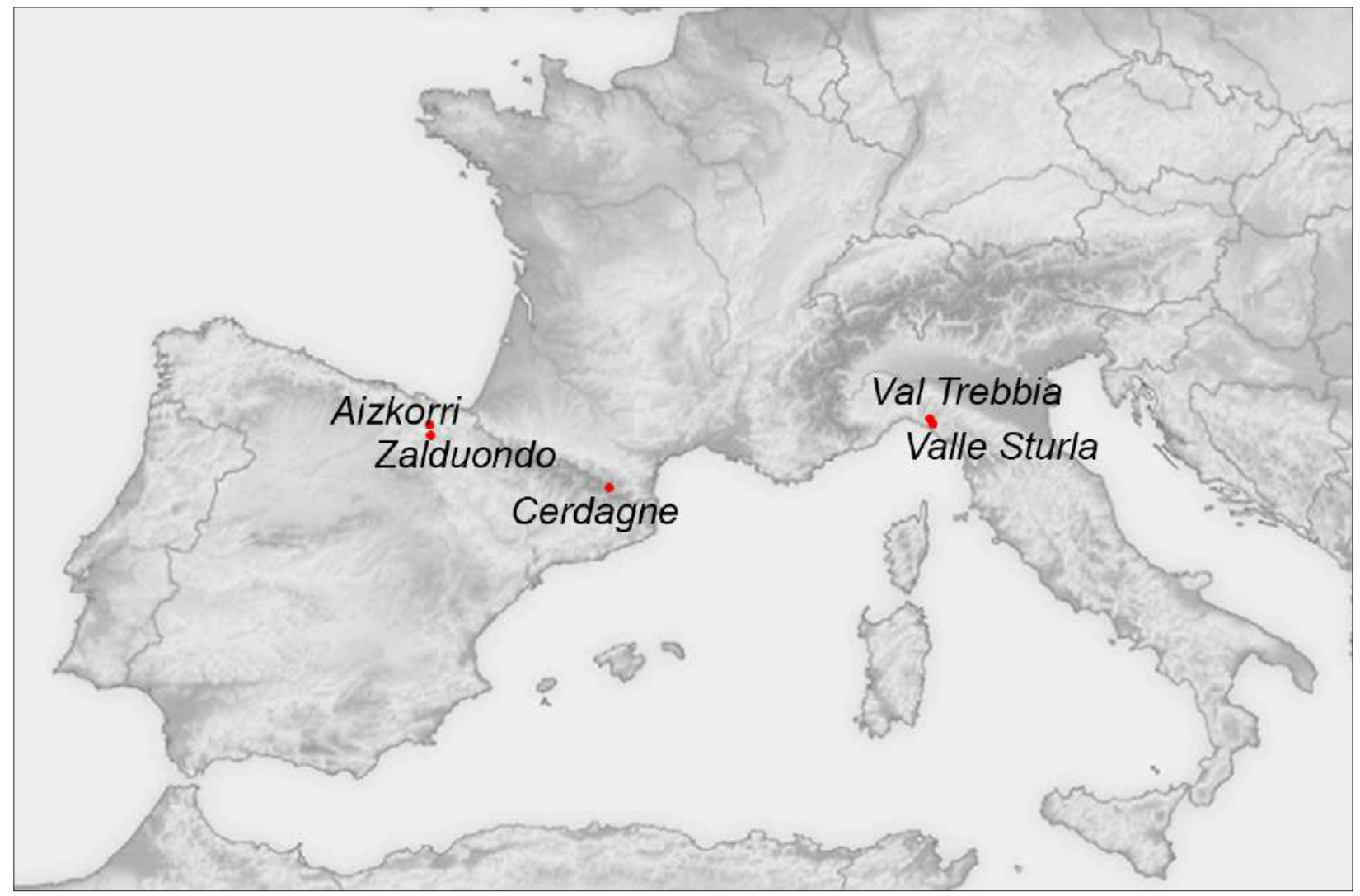

Fig. 1. Map of the project case studies in the Basque Country (Zalduondo, with Salvatierra and Barrundia, in the Eastern Alava plateau and Aizkorri in the "Parzonería general de Gipuzkoa y Alava"), the French Pyrenees (Cerdagne) and in the Ligurian Apennines (Val Trebbia and Valle Sturla).

the growth of the collaboration between archaeologists, archaeobotanists and geoarchaeologists and, at a later stage, historians. It is possible to follow the development of the archaeological approaches to the study of mountainous areas, through a series of proceedings and edited books on the subject, from Maggi et al 1991-1992, devoted in particular to husbandryl to Galop \& Catto (2014, focused on environmental history), through Leveau et al (1999), Barker \& Mattingly (2000), which belongs to the more general Populus Project, Tzorztis Delestre (2010), Van Leusen et al (2011) and Stagno (2014). The increasing number of books on the topic during the last years testifies the success of this subject in current archaeological research. The development of a new interest on commons might be related to the recent advances made by mountain archaeology, as testified by the presence in one of the sessions lOutlands and outland use - in the past, the present and the future) of the European Archaeologists Conference 2014 held in Istanbul, of three papers on the archaeology of commons, discussing about the possibility to identify commons using a landscape archaeology approach and the contribution of a long-term perspective to current theoretical discussions concerned with commons (See also, Lindholm, Sandström \& Ekman, 2013 and Oosthuizen, 2013).

The research project presented in this paper (ARCHIMEDE - Archaeology of Commons: Cultural Heritage and Material Evidences of a Disappearing Europel aims to study the historical relationships between access rights on common lands, local social groups and their environment with the objective to investigate the dynamic nature and the historical dimension of common-lands starting 
from the reconstruction of their present organisation and going back in time. The research is being developed in the Basque mountains with the Research Group on Cultural Heritage and Landscapes at University of the Basque Country lehu. eus/en/web/culturalheritage), and compared, through targeted investigations, with two areas of southern Europe, the Ligurian Apennines and French Pyrenees Ithe Laboratory of Environmental Archaeology and History -LASA at the University of Genoa (www.lasa.unige.it) and the Laboratory FRAMESPA-Terrae of the Université Toulouse Jean-Jaurès (http://framespa.univ-tlse2.fr/; Terrae: http://terrae.univ-tlse2.fr/l, that share a similar focus on analytical and multi-period investigations). (fig. 1)

Social micro-history has shown how the study of conflicts around collective resources could be the key for the investigation of the local strategies and social practices of their management (Moreno \& Raggio, 1992; see also Ingold, 2011 with particular reference to this approach). Trying to follow this research perspective, the project focuses on the study, through archaeological methods, of the countless conflicts historically connected to the rights of common resources exploitation which involved the different local social groups or settlements that shared common-lands, well documented by archival material since the Middle Ages.

During the ancien régime land even later) the ways in which land possession and usage rights were recognised involved the land's continuous use (and its written certification) with or without opposition (Raggio, 1992; 1995). Conflicts on common-lands were always connected to rights of use, among which two are the more documented:

1) conflicts connected to attempts by some local actor (or group) to appropriate a part of the common land and transform it into an individual possession through an usurpation, and

2) conflicts connected to different strategies of environmental resources management between different local groups, who share the same common-lands.

The first type had an important material dimension connected to the different phases of appropri- ation that could be archaeologically studied as the discussion in the third section tries to show. The second type perhaps cannot be directly registered in the archaeological record, but can be studied through changes in environmental resource management strategies. The case study-based discussion ( $\S$ fourth) aims to exemplify this problem. Starting from the results of the case study and the discussion on the role of conflicts in local strategies for the claiming of commons' usage rights, the conclusions are focused on the potential of this type of study in the planning of the management of current rural areas. The methodologies employed are presented in the following paragraph.

\section{A Project on the Archaeology of Com- mon-lands in Europe: Methods, Objec- tives and Expected Results}

Italian social microhistory (Grendi, 1977; 1993) has shown how "on a local, topographical scale, it is possible to compare different evidence larchival, ethnographic and archaeological): focusing on processes and contexts which produced the historical documentation as well as physical traces, the analytical approach allows us to compare and test historical documentation with the observed field data that have been collected over time and over space by conventional archaeological and ethnographical methods" (Moreno \& Raggio, 1991; see also Moreno, 1973). This approach is focused on the identification of the innumerable social configurations which composed the local societies and of the social practices through which they claim rights and managed environmental resources. Based on this research perspective, historical and historical ecology research carried on the Ligurian uplands since the 1970s has shown how this micro-analytical approach can allow the understanding of more general historical processes (Cevasco, 2007; Moreno, 1990; Quaini \& Moreno, 1973; Raggio, 1990). This perspective has promoted a discussion on the possibility to develop, only at an analytical level and through the comparison of different analytical procedures, a true dialogue 


\section{Documentary research for a first periodization of common-lands conflicts and selection of field works areas}

The extensive bibliographical analysis and the documentary research on local archives will allow to select areas of Basque mountains where conflicts on common-lands are well documented, and to make a first periodization of the conflicts documented by archival sources. The analysis of cadastral maps will help to identify the presence of private lands inside common-lands, as possible indicator of past conflict on common-lands.

\section{Historical cartography research for the reconstruction of the last centuries land use transformation}

The analysis of historical cartography, of LiDAR - DTM managed through a database connected to a GIS platform, is being realized in order to keep topographical information, and a preliminary view on the changes of vegetation cover and land use and on the presence of anomalies that could be archaeologically investigated.

\section{Surveys for the study of the topographical organization of common-lands}

Archaeological surveys, which include geo-archaeological and historical ecology observations, will take a specific attention to identify the indicator of the different practices of management of silvi-pastoral and agricultural resources, in order to permit to study the topographical organization of common lands and to qualify their resources. Particular attention will be paid to the identification of the features (presence of enclosures, hedgerows, boundaries, or other vegetational evidences) that allow to distinguish sites of permanent or temporary private occupation of piece of lands inside common lands. During these surveys, sample sites for further investigations will be chosen according to their informative potential, and preliminary visits to villages selected for the archaeology of architecture campaign will be realized.

\section{4a. Shovel tests for the study of the temporality of the different form of appropriation}

The problem of local conflicts will be addressed through circumstantial investigations. Shovel pit tests (1x0,70 m) will be realized in selected parcels of private lands inside common-lands and of sites devoted to specific uses (fodder production, agricultural cultivations,...) identified during surveys, in order to verify the continuity or the temporariness of the different uses, possible markers of local conflictuality on common-lands.

4b. Archaeology of Architecture for the study of the relationship between settlement and environmental resources management transformation

Settlements connected to the studied common-lands will be studied through Archaeology of Architecture analysis, paying a particular attention to identify the transformation of buildings connected to agro and pastoral activities (as hay-barns, stables) in order to identify the relationship between the settlement spatial organization (and its transformations) and environmental resources management systems, that could be connected with changes in the use of common-lands, and with conflicts related to them.

\section{Interpretation and elaboration of research data}

The last phase of the research will foresee the data interpretation and elaboration based on the GIS platform. The spatial analysis of the different periodizations (of landscape transformation, of uses of common-lands, of settlements, of conflicts) built during the previous phases will help to compare them, in order to identify the relationships between conflictuality on common-lands and environmental management system transformations, and to identify a list of indicators of different uses and properties.

Tab. 1. The subsequent phases of the research project. Research in the Pyrenees mountains and Ligurian Apennines will foresee only phases four-five; research in the the Basque Country as already been realised.

between different historical sources (Grendi, 2000; on this topic see also Wickham, 2002). The project presented here adopts this methodological perspective.

The research is being developed in successive phases (tab. 1) that allow an approach to the problem of the archaeological study of common-lands and the possibility to identify the relationship between different periodisations (of conflicts, of landscape and settlements transformations) derived from the study of different sources (tab. 2). This will allow the co-relation of changes in environmental resource management systems, shape of settlements, and conflict occurrence on common-lands.

Fieldwork is mainly devoted to the identification of the different forms of appropriation and their temporality (Ingold, 2000, sensu) as this is key to address not only the archaeological study of conflict but also the different strategies of common-land exploitation. Starting from the identification of evidence on different primary (pastoral, forest and agricultural) production practices, this 


\begin{tabular}{|c|c|c|c|}
\hline Research methods & Objectives & $\begin{array}{l}\text { Intermediate re- } \\
\text { sults }\end{array}$ & Results \\
\hline Bibliographic research & - State of the art and selection of study areas & \multirow{5}{*}{$\begin{array}{l}\text { Selection of study } \\
\text { areas }\end{array}$} & \multirow{2}{*}{$\begin{array}{l}\text { Periodization } \\
\text { of conflicts } \\
\text { through written } \\
\text { sources }\end{array}$} \\
\hline $\begin{array}{l}\text { Archival yet collected } \\
\text { sources analysis }\end{array}$ & $\begin{array}{l}\text { - Reconstruction and periodization of conflicts on common re- } \\
\text { sources } \\
\text { - Acquisition of topographical information on common lands } \\
\text { - Collection of information on land use and land management } \\
\text { - Collection of information on "micro institution" inside the com- } \\
\text { munities }\end{array}$ & & \\
\hline Cartographic analysis & $\begin{array}{l}\text { - Reconstruction of history of land use and land cover; maps of } \\
\text { potential rural landscapes of historical interest } \\
\text { - Acquisition of toponymical data }\end{array}$ & & \multirow{3}{*}{$\begin{array}{l}\text { Periodization } \\
\text { of last cen- } \\
\text { turies land } \\
\text { use through } \\
\text { documentary } \\
\text { sources }\end{array}$} \\
\hline $\begin{array}{l}\text { Orthophoto maps anal- } \\
\text { ysis }\end{array}$ & $\begin{array}{l}\text { - Definition of areas of archaeological visibility } \\
\text { - Documentation of recent vegetation cover transformations }\end{array}$ & & \\
\hline LiDAR- DTM analysis & - Individuation of hidden landscapes and features & & \\
\hline $\begin{array}{l}\text { Archaeological \& His- } \\
\text { torical Ecology Surveys }\end{array}$ & $\begin{array}{l}\text { - Documentation of area of common lands present in topograph- } \\
\text { ical organization (identification of effects of environmental man- } \\
\text { agement practices on vegetation; different form of occupation in } \\
\text { relation to different uses) } \\
\text { - Individuation of traces of past organization, uses and paths be- } \\
\text { tween settlement and common lands } \\
\text { - Identification of areas to submit to excavation and collect cores } \\
\text { for further LabAnalysis }\end{array}$ & \multirow[t]{3}{*}{$\begin{array}{l}\text { Selection of } \\
\text { sample sites (for } \\
\text { shovel pit and } \\
\text { archaeology of ar- } \\
\text { chitecture) }\end{array}$} & \multirow[t]{2}{*}{$\begin{array}{l}\text { Topographical } \\
\text { organization } \\
\text { of commons, } \\
\text { and hypothesis } \\
\text { on the period- } \\
\text { ization of the } \\
\text { changes in their } \\
\text { management }\end{array}$} \\
\hline $\begin{array}{l}\text { Geoarchaeological ob- } \\
\text { servations }\end{array}$ & $\begin{array}{l}\text { - Analysis of soil formative processes } \\
\text { - Collect cores for further LabAnalysis (see below for the objec- } \\
\text { tives of LabAnalysis) }\end{array}$ & & \\
\hline $\begin{array}{l}\text { Archaeology of Archi- } \\
\text { tecture }\end{array}$ & $\begin{array}{l}\text { - Reconstruction of the changes of functional spaces connected } \\
\text { with agro-silvi-pastoral systems }\end{array}$ & & $\begin{array}{l}\text { Periodization } \\
\text { of settlement } \\
\text { transformation }\end{array}$ \\
\hline $\begin{array}{l}\text { Sample archaeological } \\
\text { excavation of selected } \\
\text { sites }\end{array}$ & $\begin{array}{l}\text { - Verification of the possibility to distinguish in the stratification } \\
\text { the temporality of different phase of use and to distinguish be- } \\
\text { tween temporary and permanent occupations }\end{array}$ & \multirow{4}{*}{$\begin{array}{l}\text { Identification of } \\
\text { the markers of the } \\
\text { different form of } \\
\text { appropriation of } \\
\text { common-lands }\end{array}$} & \multirow{4}{*}{$\begin{array}{l}\text { Periodization } \\
\text { of the different } \\
\text { form of occu- } \\
\text { pation }\end{array}$} \\
\hline $\begin{array}{l}\text { Geoarchaeological } \\
\text { analysis }\end{array}$ & $\begin{array}{l}\text { - Analysis of depositional and post-depositional processes con- } \\
\text { nected to soils, and identification of previous traces of land uses } \\
\text { (cultivation, grazing, fodder production etc.) }\end{array}$ & & \\
\hline $\begin{array}{l}\text { Archaeobotanical anal- } \\
\text { ysis }\end{array}$ & $\begin{array}{l}\text { - Reconstruction of environmental resources management prac- } \\
\text { tices }\end{array}$ & & \\
\hline $\begin{array}{l}\text { Archaeometrical anal- } \\
\text { ysis }\end{array}$ & - Acquisition of chronological information & & \\
\hline $\begin{array}{l}\text { Archaeological Data in- } \\
\text { terpretation }\end{array}$ & $\begin{array}{l}\text { - Building matrix of landscape and settlements transformations } \\
\text { - Identification of common lands different organization during the } \\
\text { times }\end{array}$ & \multirow{2}{*}{$\begin{array}{l}\text { Comparative anal- } \\
\text { ysis of the differ- } \\
\text { ent series of data } \\
\text { collected }\end{array}$} & \multirow{2}{*}{$\begin{array}{l}\text { Identification } \\
\text { of the links be- } \\
\text { tween different } \\
\text { periodizations }\end{array}$} \\
\hline GIS analysis & $\begin{array}{l}\text { - Spatialization and matching data } \\
\text { - Comparing archaeological, cartographical and archival recon- } \\
\text { struction at topographic scale, for the comprehension of the tool } \\
\text { - Eventually identification of models of functioning }\end{array}$ & & \\
\hline
\end{tabular}

Tab. 2. Synthesis of the research methods employed in the project and of their objectives. 


\begin{tabular}{|c|c|c|c|}
\hline Evidence & Activity & Interpretation & Type of appropriation \\
\hline Antennaria dioica & controlled fire and pasture & $\begin{array}{l}\text { temporary cultivation or hus- } \\
\text { bandry }\end{array}$ & temporary \\
\hline Peat-bog & watering pits & husbandry & temporary \\
\hline Pollarded trees & leaf collection as fodder & husbandry & temporary \\
\hline Scattered trees & pasture & wooded pastures & temporary \\
\hline Smoothed stones & $\begin{array}{l}\text { repetitive passage of the } \\
\text { sheep in their overnight } \\
\text { stay }\end{array}$ & husbandry & temporary \\
\hline $\begin{array}{l}\text { Hedgerows and lines of } \\
\text { hawthorns or laburnum }\end{array}$ & $\begin{array}{l}\text { definition of a cultivated } \\
\text { area, excluding the access } \\
\text { of animals }\end{array}$ & $\begin{array}{l}\text { crop cultivation or fodder produc- } \\
\text { tion (meadow) }\end{array}$ & temporary \\
\hline Heap of stone & cleanings of a crop area & $\begin{array}{l}\text { temporary or permanent culti- } \\
\text { vation }\end{array}$ & temporary or permanent \\
\hline $\begin{array}{l}\text { Filtration walls (dikes) } \\
\text { in wetlands }\end{array}$ & regulation of water flow & $\begin{array}{l}\text { use as watering pits or for fodder } \\
\text { production }\end{array}$ & $\begin{array}{l}\text { temporary or perma- } \\
\text { nent?? }\end{array}$ \\
\hline Urtica dioica & permanence of livestock & intensive husbandry & permanent \\
\hline Terraces & agricultural activity & permanent cultivation & permanent \\
\hline Pottery in the field & fertilisation & permanent cultivation & permanent \\
\hline Wet-meadow & $\begin{array}{l}\text { cultivation for fodder pro- } \\
\text { duction }\end{array}$ & husbandry & permanent \\
\hline Canal & irrigation & permanent cultivation & permanent \\
\hline Stone alignment & definition of an area & $\begin{array}{l}\text { divide areas from others as prop- } \\
\text { erty sign }\end{array}$ & permanent \\
\hline Isolated hawthorns & $\begin{array}{l}\text { indication of a cultivated } \\
\text { area }\end{array}$ & $\begin{array}{l}\text { crop cultivation or fodder produc- } \\
\text { tion (meadow) }\end{array}$ & possession sign \\
\hline Shieling, malga... & seasonal settlement & husbandry & possession sign \\
\hline $\begin{array}{l}\text { Stone fences, enclo- } \\
\text { sures, walls }\end{array}$ & $\begin{array}{l}\text { division of areas from oth- } \\
\text { ers, excluding access of } \\
\text { animals }\end{array}$ & $\begin{array}{l}\text { crop cultivation or fodder produc- } \\
\text { tion (meadow) }\end{array}$ & possession sign \\
\hline
\end{tabular}

Tab. 3. Archaeological and historical ecological indicators of different agro-silvo-pastoral activities and their informative potential about permanent or temporary occupation. The references are to the Medieval and post-Medieval evidence documented during field-work during the 2006-2012 LASA research projects. Historical ecological evidence, mainly indicator species, is derived from Cevasco (2013) and for the archaeological ones, see Stagno (in press).

analysis will help to distinguish the site of temporary individual appropriation, site of usurpation, individual possessions inside common-lands and to make a list of their possible archaeologi- cal markers (see the discussion of the following section and tab. 3 for examples). For this reason, from a methodological point of view, this research adopts historical ecology's topographical approach and rural archaeology, aiming to decipher the historical practices of environmental resource management and how they were developed by local social groups (Cevasco, 2007; Moreno, 1990; Stagno, in press). This perspective is enriched by the adoption of a specific trend within agrarian archaeology that is mainly focused on the reconstruction of social structures (as hierarchies and inequalities) in pre-industrial societies through the study of field and crop systems and its connection with settlement patterns (Kirchner, 2010; Quirós Castillo, 2012). 


\section{The Archaeological Study of Conflicts on Common Resources: from the Identifica- tion of the Practices to the Study of the Different Phases of Common-lands Ap- propriation}

As outlined above, during surveys it is possible to identify many traces that could be interpreted as clues of specific management resource practices. Data identified during field survey could inform us about the presence of past, temporary or permanent cultivations, the management of water resources (of wetlands or of rivers), husbandry and other production activities. Besides archaeological methods, historical ecology observations help to identify evidence of past historical practices thanks to the presence of particular "indicator species" (flowers, herbs) or particular tree management practices (Cevasco, 2007). This type of information could inform us about the different forms of appropriation. As noted above, the historical forms to claim access rights on lands had a strong material dimension which social history defines as "possession practices" (Grendi, 1986). During the Middle Ages and the Old Regime, some agricultural practices had a ritual dimension, no doubt in relation to their high value as possession practices. This must have been more evident in a context of commons-related conflicts (Moreno, 1993). Multiple uses (not only husbandry and wood exploitation) that foresaw a temporary individual appropriation (such as temporary cultivations, fodder production, etc.) were allowed in common-lands and ruled by local customs and local (or seigneurial) statutes. However, it was not uncommon that the areas temporary occupied were not returned to collective uses but were the object of actions (improvements) aimed to define new forms of possession of the land (Raggio, 1992). This type of occupation is known as "usurpation" and always generated conflicts that often end in a permanent appropriation by the usurper and therefore implying the transfer of common land into a private possession. The process of usurpation could help to explain the several parcels of private property inside common-lands that the analysis of current cadastral maps shows. From original usurpations some particular forms of possession and use, as the Basque seles (Diaz De Durana, 2001) or the Pyrenees' cortals (Bille, Conesa $\&$ Viader, 2007) and the Ligurian ville (Moreno, 1990) have been also derived.

It is not possible to discuss here the difficulties, maybe the impossibilities, involved in the identification of common-lands through the analysis of their past use, due to the fact that, in mountain areas, grazing activities, temporary cultivations, fodder production and collection of wild herbs and fruits were documented in both common-lands and in individual possessions not devoted to permanent crop-fields and often covered with scattered trees (Beltrametti et al, 2014). It is hard to find evidence of the "legal" division between common or private property that does not correspond to the Old Regime categories (Beltrametti et al, 2014; see also Tigrino, 2015).

However, during field survey in contemporary mountain common-lands - both in (ancient) pastures and in woodlands - it is possible to identify a number of possession signs that could suggest a complex past with different forms of occupation. Fences made with stones or hedgerows with hawthorns were used to avoid the access of the flocks and, at the same time, as markers of permanent appropriations. Hawthorns are one of the more widespread vegetal possession markers in European mountains, used both as hedgerows (to indicate a temporary appropriation) and as solitary tree, as possession sign (Agirre García, Moraza Barea \& Mujika Alustiza, 2010; Azpiazu, 2011; Rendu, 2003). These signs surely refer to past phases of individual appropriation, even if today the old appropriated plot could not be recognised as a private property and is so registered as common-land. The study of the history of these sites could help reconstructing the relationship between management, environmental resources, and the activation of access rights to lands through conflicts.

Property signs are maybe one of the clearest evidences allowing the identification of perma- 
nent appropriations, but it is possible to list some other archaeological evidences that could help distinguishing between this final phase, which we can define as “individual possession inside common-lands", usurpation and temporary appropriation (such as for temporary cultivation). Pottery in the fields could inform us about manuring and on the process of agricultural colonisation through permanent field (Poirier, 2014), enclosures for animals and seasonal settlements could be indicative of the process of permanent appropriation of uplands, as documented in the reconstruction of estivage practices in the Pyrenees (Gassiot Balbé \& García Casas, 2014; Le Couedic, 2010; Orengo et al, 2014; Rendu, 2003). Other signs, as heaps of stones (Guido, Montanari \& Scipioni, 2003) suggest an occupation for temporary cultivation that, maybe, did not get to become an usurpation.

In order to go more in depth into the problem of the distinction between temporary occupation and usurpation it could be useful to discuss temporary and permanent cultivation. In all Mediterranean mountains a particular practice of temporary cultivation that foresees the employment of controlled fire in order to prepare the parcel las the Italian ronco, Spanish roturas; French essartagel is well documented (see as reference Viader \& Rendu, 2014, where a number of archaeological approaches to the study of this practice are proposed). This practice was usually allowed in common-lands, in the framework of the multiple uses of collective resources (Moreno, 1990): it was a temporary appropriation of a parcel of common-lands for two or three years, after this period the land returned to common-uses.

Osvaldo Raggio writes about the Ligurian "ronco":

I confini tra il coltivato e l'incolto, tra la proprietà individuale e il possesso collettivo erano costantemente rimodellati dalla pratica delle colture temporanee sulle comunaglie boscate con la tecnica del ronco ltaglio del bosco, abbruciamento della vegetazione arbustiva e della cotica erbosal. Qui i confini tra possesso individuale e collettivo diventavano molto sotti- li: il ronco poteva suscitare l'accusa di occupazione o usurpazione, era l'atto di possesso - concreto e rituale - più forte ed esplicito, e in molti casi di fatto costituiva la prima tappa di un processo di piena appropriazione individuale del patrimonio collettivo (Raggio, 1992: 145-46).

It is in fact well known - given its economic importance and being a common cause of conflict inside communities - that through a series of "improvements" (miglioramenti) the temporary appropriations were transformed in occupations or usurpations. After the improvements, it was difficult to make a direct restitution of the usurped parcel to the common-lands and, in many cases of conflicts, these areas became property of the usurper who paid to the community the value of the land. This type of solutions, through a "legalisation" of the usurpation, obviously depends also on the role of the usurper in the local communities and by the relationships between the local actors involved in the conflict. But the more "legal" and, at the same time, practical reason for this solution was that the usurper had made improvements - actions that changed in a durable way the characteristics of the plot - and so gained exclusive rights on the part of improved common-lands. In this case the payment was a way to solve the conflict, through a sort of privatisation, which legalised the previous usurpation.

Typical improvements were the fertilisation with animal manure - and not only with the vegetal ones derived from the spreading of the ashes of controlled fires or as the simple consequence of grazing activity - or some types of arrangement of the ground as with the construction of small terraces in the slopes (Raggio, 1992). Despite the fact that this is weak evidence, it can be archaeologically recognised and helps in discerning between evidence related to temporary appropriation (ronchi, pasture), usurpation (manure, arrangements, etc.), permanent appropriation (possession signs, permanent cultivations) and the definitive subtraction of the parcel from common uses. The following table 3 tries to provide some examples on how 


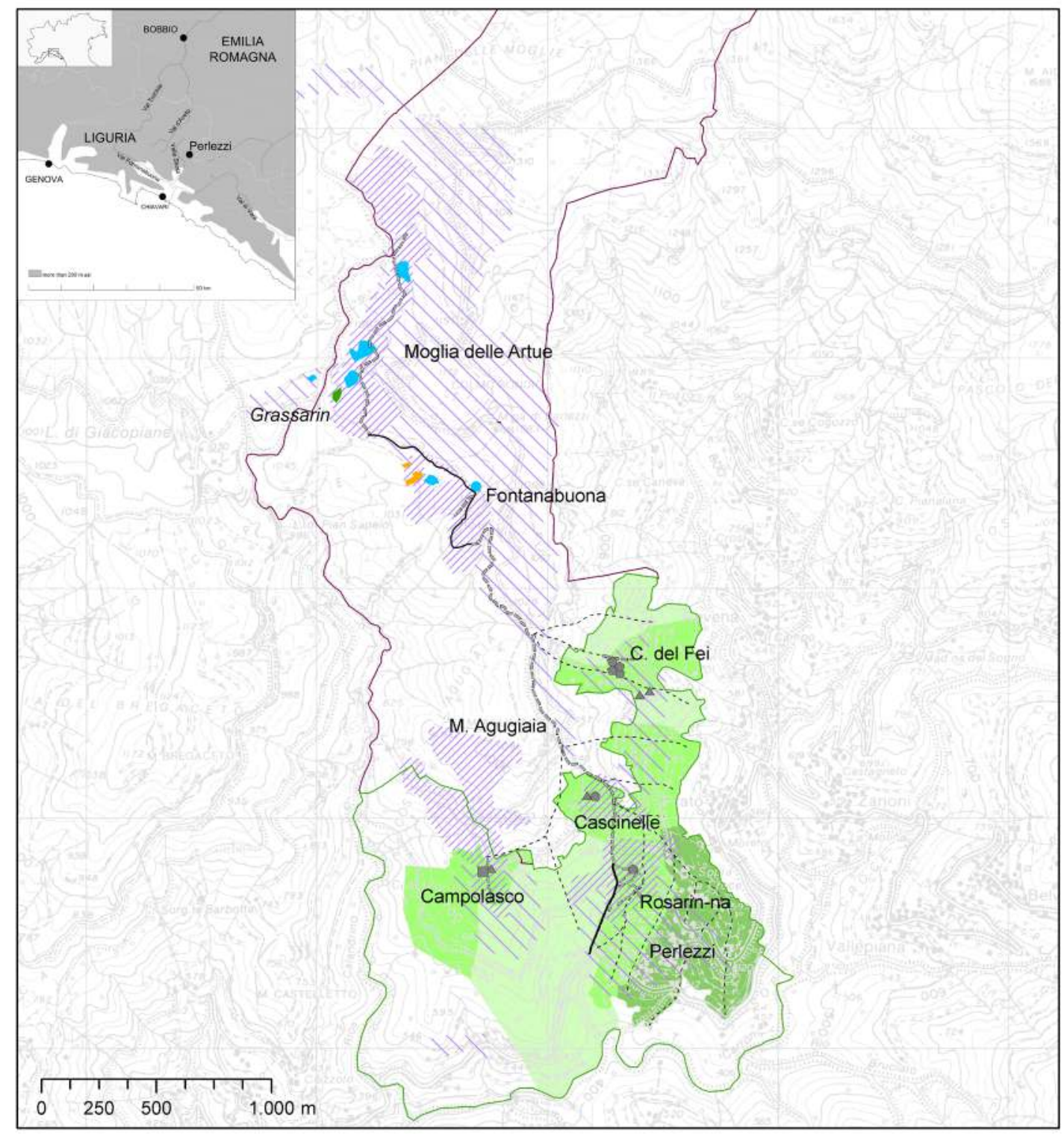

\section{Legend}

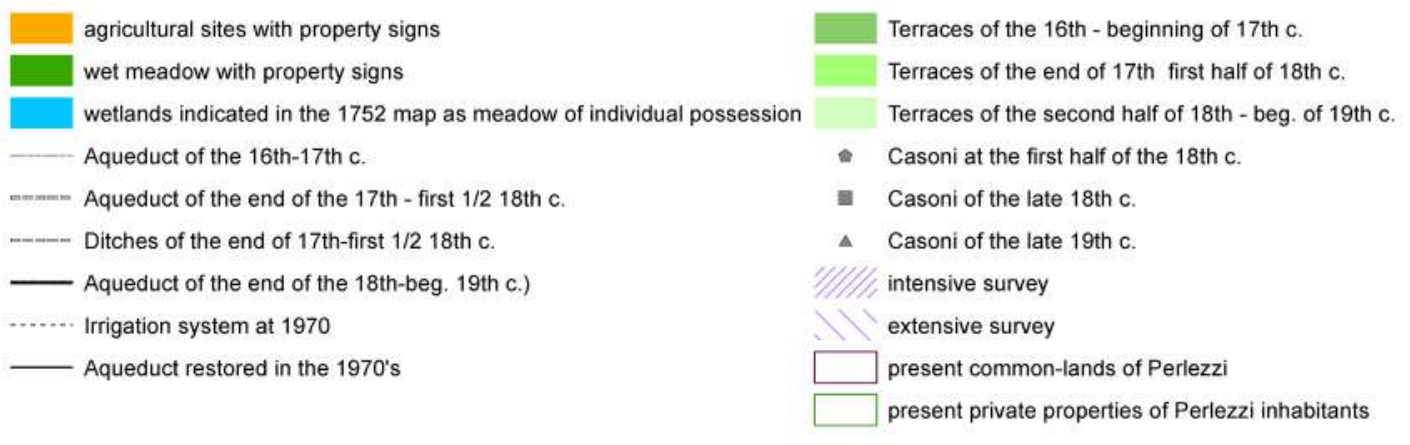

Fig. 2. Perlezzi (High Sturla valley). Surveyed area with indications of identified sites, a reconstruction of the chronology of terraces, aqueduct, and "casoni", and of the intensity of the investigation (after Stagno, in press b, modified). 


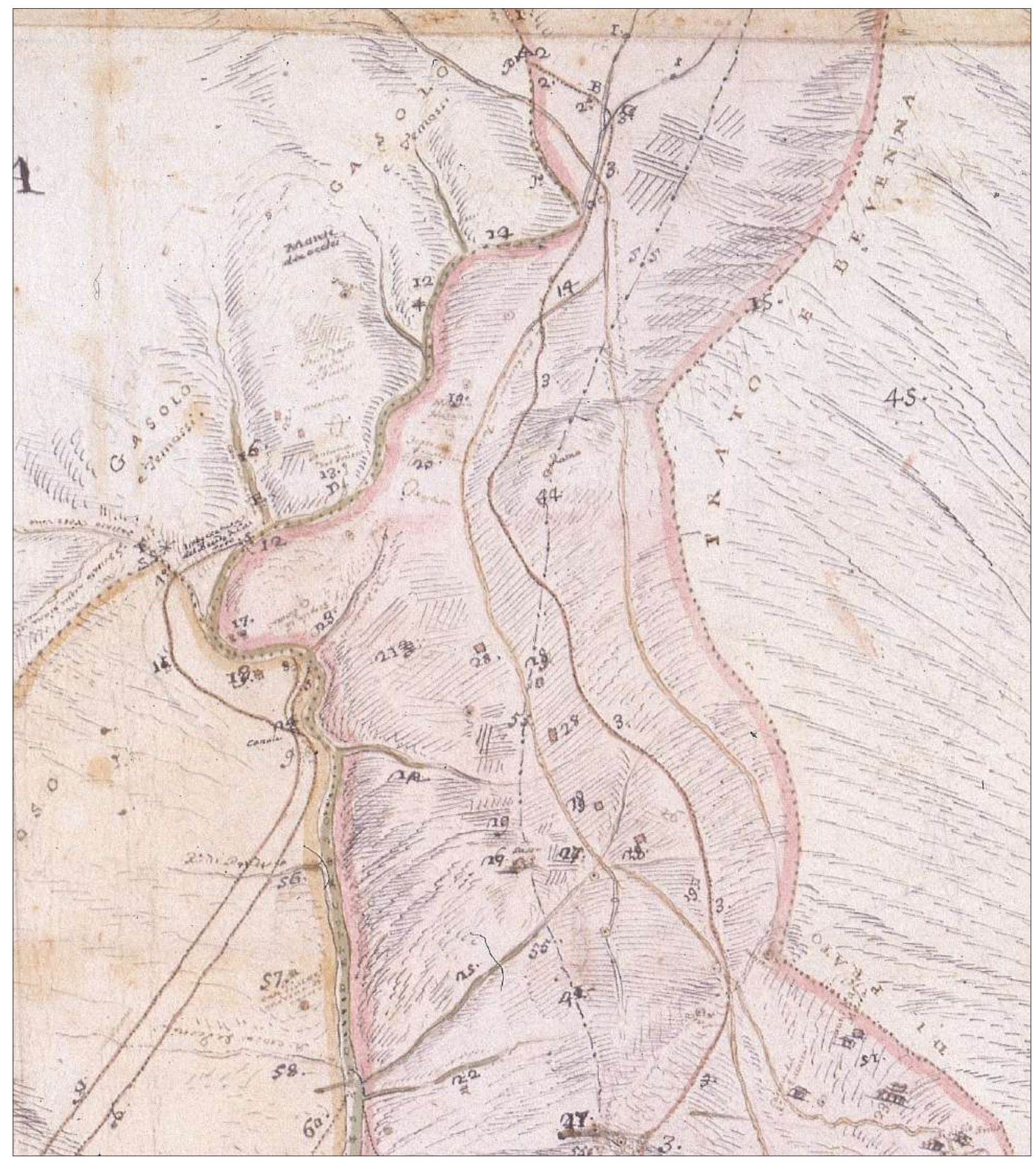

Fig. 3. Detail of the "Tipo Geometrico" of 1752 with the representation of the "prati dei particolari di Perlezzi" and of their casoni, as indicated by the map 119. Moglie Mezane; 20. Prato del Garazino anzi Grazarino; 21. Prati di Rondinare; 22. Prato del Fango con qualche poc acqua sotto li 7.8bre 1752; 27. Prati de Particolari di Perlezzi detti di Fontana bona; 28. Casoni de Particolare di Perlezzi, rovinati dal tempo, quali servivano per ritiro de loro bestiami, mentre pascolavano ne loro Prati segnati colli numeri 18., 19. 21., 29. e 40. come nel rimanente della campagna, che tra' i limiti de suoi confini ascende sino alla sommità de Monti confini del SE. Principe Doria; 29. Prato della Pietra Grossa de Particolari di Perlezzi), (Stagno \& Tigrino, 2012). 
to distinguish the different forms of appropriation from the different types of data. It is obvious that all this evidence should be considered inside its local context.

Some evidence las in the differences in the fertilisation) could be not appreciated through surveys but several analysis methods could help to identify them in an archaeological stratigraphy. Geochemical analysis lon the different percentage of phosphorus, potassium and nitrogen) and the study of Non-Pollen Palynomorphs (NPPs) could inform us about the different form of fertilisation of the soil: vegetal fertilisation (through ashes), fertilisation as consequence of grazing activity, fertilisation through manure, which could represent different phases of appropriation. The different form of pollen assemblages in the analysis of soil profiles or of wetlands deposits could distinguish between temporary and permanent cultivation (Molinari \& Montanari, 2015; Reinbold, 2014) and identify the passage from one to another. Together with the study of NPPs, these analyses could identify the different pastoral activities (Galop et al, 2006; 2011), forms of cultivation and multiple uses (Menozzi, Zotti \& Montanari, 2010; Molinari \& Montanari, 2015). In addition, direct microfossil evidence from phytoliths (plant silica cells, Piperno, 2006) and dung spherolites, which are calcareous particles produced in the digestive tract of many animal species, primarily ruminants (Canti, 1999) may provide useful evidences in order to distinguish foddering or grazing activities of herds and different fertilisation practices (i.e. Matthews, 2010; Shahack-Gross, 2011 and references therein). Viewed from the perspective of the possession practices, all the information could help us to distinguish the different phases of appropriation.

\section{From the Study of the Multiple Uses to the Study of Access Rights to Com- mon-lands: the Case Study of Perlezzi}

Until now the focus was on the problem of individual appropriation of common-lands but it is generally acknowledged that conflicts over commons are re- lated to the different management strategies of the common resources which always involved different social groups which could belong to the same or to different communities lamong the countless bibliography on these sort of conflicts, well documented everywhere in Europe, it is possible to quote Barbot, 2013; Ingold, 2008 and Zagli, 1992 as specifically referred to conflicts on water resources and in the discussed case study; for more general overview see also Charbonnier et al, 2007; Lana \& Congost Colomer, 2007; Moreno \& Raggio, 1992; Rodgers et al, 2011 and also, from a neo-institutional perspective, De Moor, Shaw-Taylor \& Warde, 2002). The archaeological record could register indirect evidence for conflicts, which can help to explain their origin and to consider them as a part of the same system of common-lands, settlements and their permanent fields.

In order to better explain this, I will employ one case study from the research developed by the Laboratory of Environmental Archaeology and History-LASA at Genoa University, started in the framework of the study of wetlands and their water perimeters (www.lasa.unige.it/progettozum) and developed during my doctoral and postdoctoral projects (Stagno, 2009; Archeologia e Storia della Società rurale 2009-2013; Stagno, in press).

The investigation was carried out in the Ligurian Apennines, High Sturla valley (fig. 2), in an area which historically belonged to the Repubblica di Genova domain (Stagno \& Tigrino, 2012). The focus is on an eighteenth century controversy on water access rights studied through archival documentation and fieldwork. The problem was connected to the origin of different aqueducts of three hamlets (Perlezzi, Caroso and Caregli) that took water from the same river, in a wide area of common lands, shared in common by the three hamlets. In order to solve the conflict, the Senate of the Repubblica di Genova sent an engineer (Domenico Carbonara) to draw a "tipo geometrico" to map the claims of each local group involved in the controversy. Based on these claims the engineer proposed to solve the controversy by dividing common-lands to define new boundaries within those common-lands. 


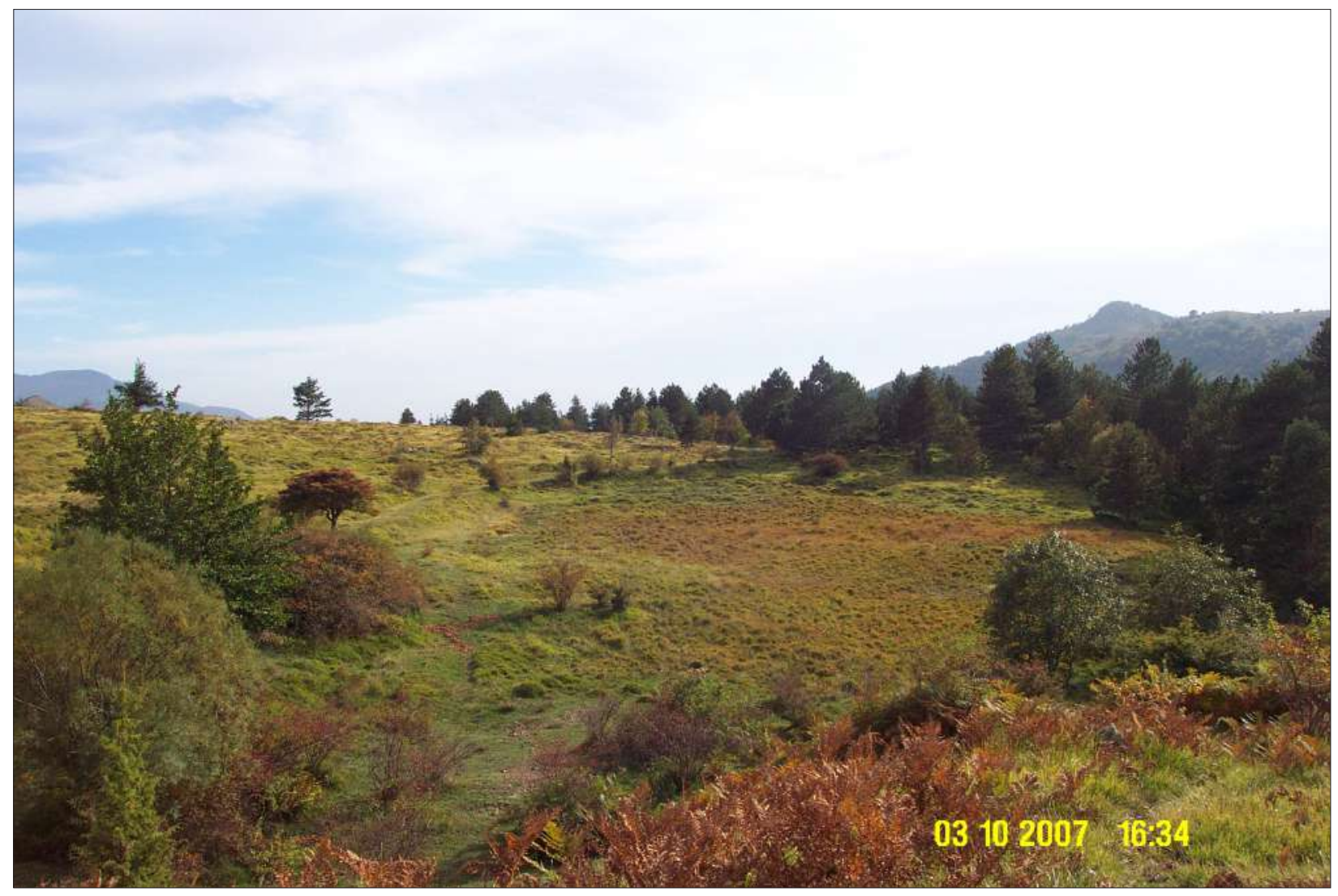

Fig. 4. The area of Moglia del Grassarino, a solitary hawthorn tree indicated a past individual possession inside common-lands (Stagno, 2009: 329, fig. 39).

It is interesting to see how the rights on common-lands (and through them on the water) of each hamlet were certified by its representatives: by declaring the practices realised, the ownership of casoni (seasonal buildings for husbandry) and above all, of some parcels of individual people inside common-lands ("prati dei particolari”, “pezzi di terra dei particolari", fig. 3). These plots of land, possibly ancient usurpations, became tools for the legitimation of the right on common-lands by the whole community of the inhabitants of the hamlet. For this reason the engineer drew them in a very accurate way and the Magistrati of the Repubblica reconstructed the history of their ownership since the sixteenth century.

During fieldworks at Perlezzi, we identified some areas that showed anomalous character- istics with respect to their surrounding land and which here defined by some markers: arboreal hawthorn (fig. 4), alignment of stones, and rows of hawthorns. The comparison between their location and that of the eighteenth century individually possessed plots of land shows that they fit. So, it is possible to identify these areas in the present landscape. It is important to underline that almost all of those are wetlands, with evidence of their past use as wet-meadow for fodder production. It is also interesting to note that in the modern cadastre all of this area is considered as common-land ("beni frazionali di Perlezzi") so it is possible to describe them as abandoned private lands (Beltrametti et al, 2014). This is a clear example of the temporality of the forms of appropriation, which I have discussed in the previous paragraph.

It is evident that the water of the aqueducts was used not in common-lands but for fields and vegetable gardens (where aqueducts brought the water). During the archaeological survey developed in the terraced slopes of Perlezzi, it was 
possible to identify different phases of the terracing process in the surroundings of the hamlet. For each phase, terraces and the channel of the aqueduct were built at the same time (Stagno, 2015). This contemporaneity allowed the dating of the different phases of terrace construction through the chronology of the channel of the aqueduct as documented in the archival and cartographical record between the early eighteenth and the first half of the twentieth centuries. The comparison showed that the more extensive phase of terracing was developed between the end of the seventeenth and the eighteenth centuries. This element helped to explain the conflicts on common-lands, which were based on a new demand for water derived from the creation of new terraced agricultural spaces. In the case of Perlezzi, this process seems to be connected to a demographic growth, but in the same period and in other areas, it is related to the intervention of a single family group las archival documentation about the payment of the aqueduct suggest for the hamlet of Caroso).

This colonisation also has a direct effect on the use of common-lands. The seasonal settlement (casoni) connected to local cattle breeding, previously located in common-lands, were abandoned and new casoni were built at the top of the terraces near common-lands. This change was probably due to the need to conciliate agricultural and pastoral activities but it also had an effect on the access to common lands and on their management. Cattle no longer stayed overnight in common-lands pastures but rather in stables located on private lands, and from there were moved daily to common-lands. This movement is well documented in several parts of the Ligurian Apennines and it is connected to the progressive development of local cattle breeding "short distance transhumance" (monticazione) in concurrence with long distance sheep transhumant breeding, which in these areas will end in the late nineteenth century (Stagno, 2015).

\section{Conclusions}

I have tried to provide some elements for an archaeological approach to the study of common-lands and their related conflicts. The different ways to study conflicts on common-lands showed in the previous paragraphs can help archaeology to achieve a deeper understanding of the study of the social practices of possession. It has already been discussed that the land is, above all, the spatial shape of the social structure and that property and ownership (possession) are relations between people and groups. Analysing different forms of usurpation and appropriation could be the first step to achieve an archaeological study of the access to collective resources and, through it, a study of the different distribution of wealth, the different local ways of social and political aggregations and finally the social stratification of local communities (Raggio, 1992: 135-36).

The study of land-related conflict allows us to address, from a social perspective, the reconstruction of the history of the local strategies of management and production of agro-silvo-pastoral resources and, in doing so, highlights the role of local knowledge in the preservation of the historical rural landscapes. In this framework, conflicts were the tool through which local actors negotiated the access rights to commons, guaranteeing a dynamic sustainability between social competition and equal/durable access to environmental resources (Beltrametti, 2013). In the discussed case study, for example, through at least two centuries of conflicts all the hamlets maintained their aqueducts, their commons and started to lose them only with the abandonment of the agro-silvo-pastoral activities after the 1950s.

Thanks to its practical character, starting from the present landscape and going back in time, archaeology (and in particular archaeological survey) and historical ecology could help to link historical reconstruction, present landscape management and preservation of cultural heritage. The identification of past land organisation-related evidence can help to individuate the positive externalities of collective management of lands and to underline 
the positive role of local practices of environmental resources management in the maintenance of environmental systems (Cevasco, 2007; Cevasco \& Moreno, 2013). Nowadays, in several European mountain areas, common-lands are rapidly disappearing as a consequence of their lack of management. So, in a hypothetical calculation of the economic benefits associated with the preservation of the collective rights of exploitation of "marginal" lands, it becomes necessary to take into account the consequences of their eventual abandonment, from which well-known environmental risks derive, such as the uncontrolled growth of secondary forest formations, hydro-geological instability, the danger of fire and the loss of biodiversity (Stagno \& Tigrino, 2012). Through the reconstruction of common land's archaeology and historical ecology, local practices can be identified and their particular history could be deepened, helping to clarify the link between local practices, resources and social articulation and contribute to planning a sustainable management of environmental and cultural resources.

\section{Acknowledgements}

This project (ARCHIMEDE - Marie Curie IEF, ehu. eus/ehusfera/archimede) has received funding from the Seventh Framework Programme of the European Union - Research Executive Agency SP3 - People under Grant Agreement 630095.

I would like to thank Diego Moreno and Carlo Montanari, Christine Rendu, and Juan Antonio Quirós Castillo for help and advice during the research. I would also like to thank Marta Portillo and Vittorio Tigrino for their bibliographical suggestion. I am especially grateful to Hector Orengo and Josep Maria Palet for all their patience and suggestions. Any errors are mine alone.

\section{References}

Agirre García J, A Moraza Barea \& JA Mujika Alustiza 2010: Los elementos físisicos como reivindicación del territorio y de sus frutos en los espacios de montaña, Munibe Suplemento, 32, 286-313.

Agrawal A, 2003: Sustainable governance of common-pool resources: context, methods, and politics, Annual Review of Anthropology, 32, 243-62.

Azpiazu JA, 2011: Los Bienes Comunales en el pasado y el presente del país Vasco, in Nervi P (ed.), Archivio Scialoja-Bolla. Annali di Studio sulla proprietà collettiva 1(2011): 65-89. Giuffré, Torino.

Barbot M, 2013: Non tutti i conflitti vengono per nuocere. Usi, diritti e litigi sui canali lombardi fra XV e XX secolo (prime indagini), in Mocarelli L (ed.), Quando manca il pane. Origini e cause della scarsità delle risorse alimentari in età moderna e contemporanea: 35-56. Il mulino, Bologna.

Barker G \& D Mattingly 2000: General Editor's Introduction: The POPULUS Project, in Francovich R, Patterson H \& Barker G (ed.), POPULUS 5. Extracting Meaning from Ploughsoil Assemblages: i-ix, Oxbow Books, Oxford.

Beltrametti G, 2013: Spazi e diritti collettivi nell'Appennino ligure (XVIII-XX sec.), Tesi di dottorato in Geografia Storica per la Valorizzazione del Patrimonio Storico Ambientale, Università di Genova.

Beltrametti G, R Cevasco, D Moreno \& AM Stagno 2014: Cultures temporaires entre longue durée et chronologie fine: traces des pratiques dans les sols, la végétation et les textes, in Viader R \& C Rendu (ed.), Cultures Temporaires et féodalité. Les cycles culturaux et l'appropriation du sol dans l'Europe Médiévale et Moderne: 235-58. Presses Universitaires du Mirail, Toulouse.

Bille E, M Conesa \& R Viader 2007: L'appropriation des Espaces Communautaires dans l'Est de éyrénées Médiévales et Modernes: Enquête sur les Cortals in Charbonnier P, P Coutrier, A Follain \& P Fournier, Les espaces collectifs dan les Campagnes, Xle -XXle siècle: 177-92. Presses Universitaires Blaise-Pascal, Clermond Ferrand.

Canti MG, 1999: The production and preservation of faecal spherulites: Animals, environment and taphonomy, Journal of Archaeological Science, 26, 251-58.

Cevasco R, 2007: Memoria Verde. Nuovi spazi per la geografia, Diabasis, Reggio Emilia.

Cevasco R, 2013: Storie per la gestione di una zona umida: le "specie indicatrici", in Cevasco R (ed.), La 
Natura della Montagna. Scritti in ricordi di Giuseppina Poggi: 155-70. Oltre edizioni, Sestri Levante.

Cevasco R \& D Moreno 2013: Rural Landscapes: the Historical Roots of Biodiversity, in Agnoletti M (ed.), Italian Historical Rural Landscapes: 141-152. Springer, Dordrecht.

Charbonnier P, P Coutrier, A Follain \& P Fournier 2007: Les espaces collectifs dan les Campagnes, Xle -XXle siècle, Presses Universitaires Blaise-Pascal, Clermond Ferrand.

De Moor M, L Shaw-Taylor \& P Warde 2002: The Management of Common Land in North West Europe, circa 1500-1850, Brepols, Turnhout.

Díaz De Durana JR, 2001: Para una historia del monte y del bosque en la Guipuzcoa bajomedieval: los seles. Titularidad formas de cesión y de explotación, Anuario de Estudios Medievales, 31(1), 49-73.

Galop D \& N Catto 2014: Environmental History of European High Mountain, Quaternary International 353, 1-266.

Galop D, T Houetl, F Mazier, G Leroux \& D Rius 2011: Grazing activities and biodiversity history in the Pyrenees: New insights on high altitude ecosystems in the framework of a Human-Environment Observatory, PAGES news, 19(2), 53-55.

Galop D, F Mazier, C Brun \& A Buttler 2006: Modern pollen assemblages from grazed vegetation in the western Pyrenees, France: a numerical tool for more precise reconstruction of past cultural landscapes, The Holocene, 16(1), 91-103.

Gassiot Balbé E \& D García Casas 2014: Histories d'ovelles i pastures. Arqueoiogia deis darrers segies de ramaderiaa l'alta muntanya, L'arqueologia del món modern i contemporani, 78, 452-70.

Grendi E, 1977: Micro-analisi e storia sociale, in Quaderni storici, 35, 506-20.

Grendi E, 1986: La pratica dei confini: Mioglia contro Sassello (1715-1745), Quaderni storici, 63(21), 81146.

Grendi E, 1993: Storia di una storia locale: perchè in Liguria (e in Italia) non abbiamo avuto una "Local History"?, Quaderni storici, 82, 141-97.

Grendi E, 2000: Storia della società e del manufatto urbano: riflessioni di un incompetente, in Lanaro P., Marini P. e Varanini G. M. (eds.), Edilizia privata nella Verona rinascimentale,14-22. Electa, Milan.
Guido MA, C Montanari \& S Scipioni 2003: Il paesaggio colturale nei dintorni di Casanova di Rovegno (GE) dal VII-VIII sec. d.C.: dati archeobotanici per l'area di Pian delle Groppere, Archeologia Postmedievale, 6(2002), 117-24.

Kirchner H, 2010: Por una arqueología agraria. Perspectivas de investigación sobre espacios de cultivo en las sociedades medievales hispánicas, Archaeopress, Oxford.

Ingold A, 2008: Les sociétés d'irrigation: bien commun et action collective, Entreprise et histoire, 50(1), 19-35.

Ingold A, 2011: Écrire la nature. De l' histoire sociale à la question environnementale?, Annales. Histoire, Sciences Sociales, 66, 11-29.

Ingold T, 2000: The temporality of the landscape, in T Ingold (ed.), The perception of the environment: essays in livelihood, dwelling and skill: 189-208. Routledge, London.

Lana Berasáin JM \& R Congost Colomer (coords.) 2007: Campos cerrados, debates abiertos. Análisis histórico de la propiedad en Europa (siglos XVI$X I X)$, Colección Historia, 22, Universidad Pública de Navarra, Pamplona.

Le Couedic M, 2010: Les pratiques pastorales d'altitude dans une perspective ethnoarchéologique. Cabanes, troupeaux et territoires pastoraux pyrénéens de la préhistoire à nos jours, Thèse de doctorat, Université François Rabelais de Tours.

Leveau P, F Trément, K Walsh \& G Barker (ed.) 1999: Environmental Reconstruction in Mediterranean Landscape Archaeology, Oxbow Books, Oxford.

Lindholm KJ, E Sandström \& AK Ekman 2013: The Archaeology of the Commons, Journal of Archaeology and Ancient History, 10, 2-49.

Maggi R, R Nisbet \& G Barker (ed.) 1991-1992: Archeologia della Pastorizia nell'Europa Meridionale : atti della tavola rotonda internazionale : Museo Archeologico per la Preistoria e Protoistoistoria del Tigullio, Chiavari, 22-24 settembre 1989, Istituto Internazionale di Studi Liguri, Bordighera.

Matthews W, 2010: Geoarchaeology and taphonomy of plant remains and microarchaeological residues in early urban environments in the Ancient Near East, Quaternary International, 214, 98-113.

Menozzi BI, M Zotti \& C Montanari 2010: A non-pollen 
palynomorphs contribution to the local environmental history in the Ligurian Apennines: a preliminary study, Vegetation History and Archaeobotany (19), 503-12.

Molinari C \& C Montanari (in press): Interdisciplinary approach for reconstructing an alder-based historical agricultural practice of the Eastern Ligurian Apennines (NW Italy). Environmental Archaeology.

Moreno D, 1973: La colonizzazione dei “Boschi d'Ovada”, XVI-XVII secc., Quaderni storici, 24 (8-3), 977-1016.

Moreno D, 1990: Dal documento al terreno. Storia e archeologia dei sistemi agro-silvo-pastorali, II mulino-ricerche, Bologna.

Moreno D, 1993: Storia delle risorse ambientali e forme di appropriazione, in Carletti F (ed.), Demani civici e risorse ambientali: 61-76. Jovene, Napoli.

Moreno D \& 0 Raggio 1990: The making and fall of an intensive pastoral land-use system. Eastern Liguria, 16-19th centuries, in Maggi R, Nisbet R \& R Barker (ed.), Archeologia della pastorizia nell'Europa meridionale, Chiavari 22-24 settembre 1989: 193-217. Istituto internazionale di studi liguri, Museo Bicknell, Bordighera.

Moreno D \& 0 Raggio (ed.) 1992: Risorse collettive, “Quaderni Storici”, 81, 27(3): 801-52. II mulino, Bologna.

Oosthuizen S, 2013: Tradition and Transformation in Anglo-Saxon England: Archaeology, Common Rights and Landscape, Bloomsbury Academic, London.

Orengo HA, JM Palet, A Ejarque, Y Miras \& S Riera 2014: The historical configuration of a high mountain UNESCO World Heritage Site: the agropastoral Cultural Landscape of the Madriu-Perafita-Claror Valley, Archeologia Postmedievale, 17(2013), 333-43.

Ostrom E, 1990: Governing the Commons: The Evolution of Institutions for Collective Action, Cambridge University Press, Cambridge/New York.

Piperno DR, 2006: Phytoliths: A comprehensive guide for archaeologists and paleoecologists, AltaMira Press, Lanham, MD.

Poirier N, 2014: Indices archéologiques d'intensification agraire et dynamiques spatiales des terroirs, in Viader R \& C Rendu (ed.), Cultures Temporaires et féodalité. Les cycles culturaux et l'appropriation du sol dans l'Europe Médiévale et Moderne: 117-32. Presses Universitaires du Mirail, Toulouse.
Quaini M \& D Moreno 1973: Archeologia e Geografia del Popolamento, Quaderni storici, 24(8-3).

Quiròs Castillo JA, 2012: Arqueología del campesinado medieval: la aldea de Zaballa, Universidad del Pais Vasco, Servicio Editorial, D.L. 2012, Bilbao.

Rackham 0, 1976: Trees and Woodland in the British Landscape, J.M. Dent, London.

Raggio 0, 1990: Faide e parentele. Lo stato genovese visto dalla Fontanabuona, Einaudi, Torino.

Raggio 0, 1992: Forme e pratiche di appropriazione delle risorse. Casi di usurpazione delle comunaglie in Liguria, Quaderni storici, 79(1), 135-69.

Raggio 0, 1995: Norme e pratiche. Gli statuti campestri come fonti per una storia locale, Quaderni storici, 88, 155-94.

Reinbold A, 2014: Precevoir les cultures temporaires dans les analysis palynologiques du Massif armorican, in Viader R \& C Rendu (ed.), Cultures Temporaires et féodalité. Les cycles culturaux et l'appropriation du sol dans l'Europe Médiévale et Moderne: 133-147. Presses Universitaires du Mirail, Toulouse.

Rendu C, 2003: La montagne d'Enveig, un estive pyréneénne dans la longue durée, Ed. Du Trabucaire, Perpignan.

Rodgers CP, EA Straughton, AJL Winchester \& M Peraccini 2011: Contested Common Land: Environmental Governance Past and Present, Earthscan, London.

Rotheram ID, 2013: Cultural Severance and the Environment. The Ending of Traditional and Customary Practice on Commons and Landscapes Managed in Common, Springer, Dordrecht.

Rotherham ID, M Agnoletti \& C Handley 2010: End of Tradition? Part I - History of Commons and Commons Management (Cultural Severance and Commons Past) - Part 2 Commons: Current Management and Problems (Cultural Severance and Commons Present), Venture House, London.

Shahack-Gross R, 2011: Herbivorous livestock dung: formation, taphonomy, methods for identification, and archaeological significance, Journal of Archaeological Science, 38, 205-18.

Stagno AM, 2009: Archeologia rurale: spazi e risorse. Approcci teorici e casi di studio, Tesi di Dottorato in Geografia storica per la valorizzazione del patrimonio storico-ambientale, Università degli Studi di Genova. 
Stagno AM, 2014: Carved mountain. Engraved stones. Contribution to an archaeology of resources of Mediterranean mountains, Archeologia Postmedievale, 17(2013), 13-439

Stagno AM, 2016: Seasonal settlements and husbandry resources in Ligurian Apennines (17-20 c.), in Collins J, M Pearce M \& F Nicolis (eds.), Summer farms: Seasonal exploitation of the uplands from prehistory to the present: 67-88. Quinox, Sheffield.

Stagno AM, (in press): Lo spazio locale dell'archeologia rurale. Risorse ambientali e insediamenti nell'Appennino ligure tra XV e XX secolo, Florence.

Stagno AM \& V Tigrino 2012: Risorse locali, conflitti e istituzioni. Il rapporto tra beni comuni, proprietà particolari e intervento "pubblico" (Appennino Ligure, XVIII-XX s.), in Nervi P (ed.), Archivio Scialoja-Bolla. Annali del Centro studi e documentazione sui demani civici e le proprietà collettive 1.2012: 261-302. Giuffré, Milan.

Tigrino V, 2015: Sovranità, comunità, possesso e lavoro nell'Appennino imperiale: intorno ad una mappatura settecentesca dell'Alta val d'Aveto (Genova/Liguria), in Leggero R (ed.), Comunità e organizzazione del lavoro in area alpina e prealpina tra Medioevo ed Età moderna: 215-253. MAP, Mendrisio.

Tzortzis S \& X Delestre 2010: Archéologie de la montagne européenne. Actes de la table ronde internationale de Gap, Errance, Paris/Centre Camille Jullian, Aix-en-Provence.

Van Leusen M, G Pizziolo \& L Sarti 2011: Hidden Landscapes of Mediterranean Europe. Cultural and methological biases in the pre- and protohistoric landscape studies. Proceeding of the International Meeting (May 25-27, 2007), Archaeopress, Oxford.

Viader R \& C Rendu 2014: Cultures Temporaires et féodalité. Les cycles culturaux et l'appropriation du sol dans l'Europe Médiévale et Moderne, Presses Universitaires du Mirail, Toulouse.

Wickham C, 2002: Edoardo Grendi e la cultura materiale, Quaderni storici, 110, 323-32.

Zagli A, 1992: Pratiche e forme d'uso collettive in un ambiente palustre: il bacino di Bientina in Toscana, in Moreno D \& 0 Raggio (ed.) Risorse collettive, “Quaderni Storici”, 81, 27(3): 801-52. Il Mulino, Bologna. 
